\title{
Labor Relations Board Regulation of Parochial Schools: A Practical Free Exercise Accommodation
}

\author{
Robert J. Pushaw, Jr.
}

The Catholic Church has steadfastly resisted efforts by labor relations boards to protect the statutory rights of parochial school ${ }^{2}$ teachers who have attempted to organize and bargain collectively. ${ }^{2}$ Church leaders have alleged that labor board jurisdiction violates the First Amendment religion clauses by interfering with the educational mission of inculcating Catholic faith and values. ${ }^{3}$ Courts have either accepted this argument and excepted sectarian schools from labor relations acts ${ }^{4}$ or dismissed this claim and permitted unrestricted regulation. ${ }^{5}$ These contradictory approaches illustrate the complexity of a constitutional question which has bedeviled labor boards, judges, and scholars since 1973.

1. This Note will focus on Catholic ("parochial") schools for two reasons. First, they comprise the majority of America's sectarian educational institutions. NArIoNAI. CENTER FOR Educ. STATISTICS,

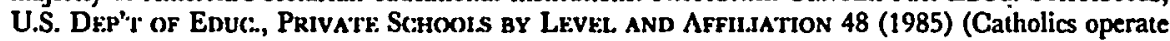
$59 \%$ of church schools and educate $78 \%$ of students attending religious schools). See also OfFicisl CArHot.lc: DiRficitory 1-2 app. (1984) (over 10,000 schools serve 3.65 million students and employ 127,300 lay teachers). Second, all the relevant caselaw concerns Catholic schools. See infra Section I.

This Note uses the term "Church" to signify the Catholic Church. The analysis developed herein might apply to schools operated by other denominations; however, each religion's doctrines may raise distinctive problems.

2. Both federal and state labor boards have regulated parochial schools. The National Labor Relations Act (NLRA), 29 U.S.C. $\$ \S 151-69$ (1982), establishes National Labor Relations Board (NLRB) jurisdiction over all employers affecting interstate commerce-including private schools. See Windsor School, Inc., 200 N.L.R.B. 991 (1972). See also infra notes 9, 11, 12, \& 18 (NLRB parochial school cases). Board oversight of sectarian schools ended, however, with NLRB v. Catholic Bishop of Chicago, 440 U.S. 490 (1979) (construing NLRA as inapplicable to church schools to avoid serious constitutional conflicts).

Because the NLRA does not cover parochial schools, states are not preempted from regulating this area. See infra notes 35 \& 50. For example, New York's Labor Relations Act was amended to include religious employers, and the state board's jurisdiction has been upheld against the clergy's religion clause claims. See Catholic High School Ass'n v. Culvert, 753 F.2d 1161 (2d Cir. 1985). Accordingly, this Note will develop guidelines for state labor boards. Nonetheless, the generic term "labor boards" will be used, since the suggested approach would be equally applicable to the NLRB if Congress amended the federal act to include religious schools.

3. See infra Section $\mathbf{I}$.

4. See NLRB v. Catholic Bishop, 440 U.S. 490 (1979).

5. See Catholic High School Ass'n v. Culvert, 753 F.2d 1161 (2d Cir. 1985).

6. Some commentators have argued that application of labor acts to parochial schools violates the First Amendment. See, e.g., Laycock, Towards a General Theory of the Religion Clauses: The Case of Church Labor Relations and the Right to Church Autonomy, 81 ColvM. L. Rev. 1373 (1981) (free exercise clause encompasses church's right to autonomy in managing its schools free from labor board interference); Bastress, Government Regulation and the First Amendment Religion 
This Note argues that the governmental interest in extending statutory guarantees to lay faculty ${ }^{7}$ can be accommodated with the Church's free exercise right to control religious aspects of Catholic education. Section I discusses the conflicting judicial treatment of the First Amendment issues raised by parochial school labor cases. Section II examines the religious and historical context of Catholic lay teacher unionization. Incorporating this factual background, Section III offers a constitutional re-analysis and demonstrates that labor acts can be applied in a manner that preserves the religious rights of Church employers. Labor boards must use their statutory discretion ${ }^{8}$ to focus solely on secular matters-exercising power over parochial schools that meet objective jurisdictional standards, enforcing the duty to bargain over "bread and butter" employment terms only (e.g., salaries and benefits), and processing those unfair labor practice charges that require no inquiry into religious doctrine. Courts must reject general constitutional challenges to such modified enforcement of labor acts.

\section{The Parochial School Labor Relations Cases}

\section{A. NLRB Assertion of Jurisdiction and the Initial Judicial Reaction}

In the early 1970's, the NLRB began to exercise jurisdiction whenever a Gatholic school's volume of interstate commerce met established monetary criteria." However, the Board declined to handle "completely

Clauses-An Analysis of the NLRB Jurisdiction Over Parochial Schools and Their Teachers, 17 DuQ. L. REv. 291 (1978) (Board jurisdiction offends religion clause values of individualism and pluralism); Durso \& Brice, NLRB v. The Catholic Bishop of Chicago: Government Regulation Versus First Amendment Religious Freedoms, 24 Sr. Louls U.L.J. 295 (1980) ("entanglement" doctrine prohibits regulation of church schools); Pfeffer, Unionization of Parochial School Teachers, 24 Sr. Lovis U.L.J. 273 (1980) (compulsory collective bargaining violates clergy's constitutional rights); Comment, The Free Fixercise Clause, the NLRA, and Parochial School Teachers, 126 U. PA. L. Rrv. 631 (1978) [hereinafter Comment, Free Exercise] (free exercise bars NLRB interference).

For various defenses of labor board regulation, see, e.g., Kryvoruka, The Church, the State and the National Labor Relations Act: Collective Bargaining in the Parochial Schools, 20 WM. \& MARY L. REv. 33 (1978) (government interest in enforcing NLRA outweighs any incidental religious infringements); Warner, NLRB Jurisdiction over Patochial Schools: Catholic Bishop of Chicago v. NLRB, 73 Nw. U.L. Rrv. 463 (1978) (Board regulation correct as policy and constitutional matter); Note, The Religion Clauses and NLRB Jurisdiction over Parochial Schools, 54 NoTRE DAME. LAW. 263 (1978) [hereinafter Note, Religion Clauses] (NLRB jurisdiction consistent with overall government regulation of religious schools); Comment, Labor Relations in Parochial Schools: Should Lay Teachers Be Denied Protection of the General Laws?, 17 SAN Diego L. REv. 1093 (1980) [hereinafter Comment, Labor Relations] (parochial school teachers should not forfeit statutory labor rights).

7. Only lay teachers have unionized; "religious" faculty (nuns, brothers, and priests) maintain a separate bargaining relationship with Catholic schools. See infra note 18.

8. While legislatures could enact special guidelines for labor board regulation of parochial schools, in practice they prefer to establish general policies and procedures, authorizing boards to adapt these standards to particular enterprises. For examples of NLRB discretion, see NLRA, 29 U.S.C. § 164 (c)(1) (1982) (decision to assert or decline jurisdiction); id. $\$ 159$ (a)-(c) (designating appropriate bargaining unit); id. $\S 158$ (prosecuting unfair labor practice charges).

9. The Board first intervened in Roman Catholic Archdiocese of Newark, 204 N.L.R.B. 159 (1973).

10. The NLRB intercedes only when a union files a representation petition on behalf of employces. NLRA, 29 U.S.C. § 159(c) (1982). The Board conducts a preliminary inquiry, analyzing the employer's operation and determining whether its volume of interstate commerce meets minimum 
religious" schools such as seminaries and instead regulated only those "religiously associated." 11 This standard engaged the NLRB in making constitutionally problematic judgments about internal Church affairs. ${ }^{12} \mathrm{Nev}-$ ertheless, between 1973 and 1977 courts permitted Board jurisdiction. For example, the Second Circuit assumed that such regulation was proper. ${ }^{13}$ Similarly, the Seventh Circuit in Grutka v. Barbour ${ }^{14}$ lifted a lower court order enjoining the NLRB from processing unfair labor practice charges against the Diocese of Gary, Indiana, and ruled that the usual NLRA review procedure adequately protected the Church's constitutional rights. ${ }^{15}$ While not necessarily endorsing the Board's actions, Grutka rejected the argument that NLRB oversight automatically breaches the First Amendment. ${ }^{16}$

Other judges displayed more sympathy to Church concerns. In Caulfield v. Hirsch, ${ }^{17}$ a federal district court prohibited the Board from taking jurisdiction over Philadelphia Catholic elementary schools. ${ }^{18}$ Repudiating Grutka as "incorrectly decided," the Caulfield court reasoned that the Church sought not mere judicial review of an administrative order, but

jurisdictional standards, which the Board has discretion to set. During the period when the NLRB was asserting jurisdiction over parochial schools, the threshold was $\$ 1$ million in revenues and $\$ 50,000$ in out-of-state purchases. 29 C.F.R. $\$ 103.1$ (1977).

11. See Roman Catholic Archdiocese of Baltimore, 216 N.L.R.B. 249, 250 (1975).

12. See, e.g., Cardinal Timothy Manning, 223 N.L.R.B. 1218, 1218 (1976) (Board "do[es] not agree that the [Los Angeles Archdiocesan] schools are religious institutions intimately involved with the Catholic Church").

13. Berause the Church did not raise constitutional objections, the court never reached the religion clause issues. See Nazareth Regional High School v. NLRB, 549 F.2d 873 (2d Cir. 1977) (Brooklyn); NLRB v. Roman Catholic Diocese of Brooklyn, 535 F.2d 1387 (2d Cir. 1976).

14. 549 F.2d 5 (7th Cir.), cert. denied, 431 U.S. 908 (1977).

15. Id. at 7-10. The NLR $\Lambda, 29$ U.S.C. $\$ 160$ (1982), requires exhaustion of administrative remedies as a prerequisite to federal jurisdiction. 549 F.2d at 7 . The court rejected as premature the Church's request for an injunction before any factual record had been developed. Id. at 8-9.

16. Id. at 8-10.

17. 95 L.R.R.MI. 3164 (E.D. Pa. 1977), discussed in Case Note, 1978 WIS. L. REv. 927.

18. The court declared an establishment clause "entanglement" violation because of the inseparability of teacher employment conditions from the schools' religious mission. Id. at 3169-80. In Archdiocese of Philadelphia, 227 N.L.R.B. 1178, 1181-82 (1977), the Board had determined that all lay teachers in diocesan elementary schools constituted an appropriate bargaining unit. The Church then sought an injunction, arguing that a multi-school unit destroyed the traditional autonomy of parish priests in running elementary schools. 95 L.R.R.M. at 3165-66. See infra note 133 and accompanying text.

The Caulfield court also accepted the Church's dubious contention that a lay faculty unit would disrupt the "single undivided community of faith" composed of religious and lay teachers. 95 L.R.R.M. at 3176. But see Comment, Free Exercise, supra note 6, at 646-47 (Philadelphia Archdiocese had voluntarily negotiated with separate lay teacher union for nine years prior to Caulfield without any discord). Bargaining with lay teachers should be no more detrimental to faculty unity than the traditional Church practice of negotiating employment terms and conditions (e.g., stipend, benefits, and housing) with agents from national religious orders that supply teachers. See J. Goulin, WoRI.DI.Y Goons 312-14 (1971). Moreover, lay-only bargaining units avoid the possibility of Board interference in disputes between religious faculty and the Church. See Nazareth Regional High School v. NLRB, 549 F.2d 873, 879 n.3 (2d Cir. 1977) (affirming propriety of excluding religious teachers). 
rather relief from the NLRB itself for exceeding its statutory and constitutional authority. ${ }^{19}$

\section{B. NLRB v. Catholic Bishop of Chicago}

The landmark case of NLRB v. Catholic Bishop ${ }^{20}$ stemmed from the refusal of the Chicago Archdiocese to recognize a Board-certified high school lay teachers' union. The Seventh Circuit attacked the NLRB's "completely religious/religiously associated" jurisdictional inquiry as an abuse of discretion which imposed a government determination of a school's spiritual nature on Church authorities. ${ }^{21}$ Rejecting the possibility of accommodation, the court held that the Board had violated the religion clauses by becoming "entangled" in religious affairs and by forcing the Bishop to share with unions his canonical decision-making authority. ${ }^{22}$

The Supreme Court affirmed on statutory grounds alone. ${ }^{23}$ Chief Justice Burger deemed First Amendment conflicts inescapable because NLRB regulation would impair the Bishop's control over teachers, who played a key role in the schools' religious mission. ${ }^{24}$ The Court assumed that the Board would define "mandatory" subjects of collective bargaining to encompass management issues such as curriculum, thus forcing the Church to negotiate religious policy, ${ }^{25}$ and that NLRB investigators would question the clergy's doctrinal judgments. ${ }^{28}$ The Chief Justice avoided these potential constitutional problems by requiring "the affirmative intention of Congress clearly expressed" to include church schools

19. Caulfield, 95 L.R.R.M. at 3167-68.

20. 440 U.S. 490 (1979). For discussion of Catholic Bishop, see Recent Cases, 84 Dick. L. Rev. 337 (1980); Case Note, 20 Santa Cl.ara L. Rev. 259 (1980); Casenote, 11 Tex. Tech L. Rev. 679 (1980); Note, 54 Tul.. L. Rev. 786 (1980); Case Comment, 58 Wash. U.L.Q. 173 (1980); Casenote, 24 Wayne: L. RFv. 1439 (1978).

21. Catholic Bishop v. NLRB, 559 F.2d 1112, 1118-23 (7th Cir. 1977), affd on other grounds, 440 U.S. 490 (1979).

22. Id. at 1124-31. Treating the religion clauses jointly under a "wall of separation" standard instead of distinguishing them, the court incorrectly applied establishment cases dealing with parochial school aid to the collective bargaining contexl, which raises free exercise issues. See 559 F.2d at 1113, $1118-19,1124,1129,1131$ (collapsing religion clauses); id. at 1119-24, 1130-31 (discussing "parochaid" cases). The court's policy justification reflects such analytical confusion: "the Board is cruelly whip-sawing schools by holding that institutions too religious to receive government assistance are not religious enough to be excluded from its regulation." Id. at 1119. However, the establishment clause bar against direct support to sectarian schools does not relieve church employers of the duty to comply with government regulations. See infra note 104. Furthermore, the court ignored the fact that religious schools receive certain forms of assistance. See, e.g., Wolman v. Walter, 433 U.S. 229 (1977) (permitting aid for books, testing, and remedial help).

23. NLRB v. Catholic Bishop, 440 U.S. 490 (1979).

24. Id. at 501-04.

25. Id. at 502-03. The Court mistakenly assumed that the public school model (all management topics subject to negotiation) would be applied to church schools. See infra notes 80 and 85-89.

26. 440 U.S. at 502. Chief Justice Burger cited Board questioning of a Catholic school priestadministrator about liturgies to illustrate such unconstitutional interference. Id. at 507-08 app. 
within the NLRA. ${ }^{27}$ Finding no such purpose, ${ }^{28}$ the Court held the Act inapplicable-a departure from its usual expansive interpretation. ${ }^{20}$

Justice Brennan led four dissenters in assailing the majority for "inventing" a canon of statutory construction to "amend" the NLRA, ${ }^{30}$ and argued that the Act's text (extending to "all employers" except eight specified categories) and legislative history (Congress rejected an amendment to exempt religious employers) revealed an intent to protect parochial school teachers. ${ }^{31} \mathrm{He}$ also noted that an exception created solely for church schools generated an establishment clause question. ${ }^{32}$

\section{Catholic High School Association v. Culvert}

Catholic Bishop invited further confusion at the state statutory level. In Catholic High School Association v. Culvert, ${ }^{33}$ the Second Circuit ruled that the New York State Labor Relations Board (SLRB) had properly exercised jurisdiction over an Archdiocesan labor dispute ${ }^{34}$ because the State Labor Relations Act explicitly covered employees of religious and educational organizations. ${ }^{35}$ Writing for the court, Judge Cardamone disapproved the Catholic Bishop dictum that labor board regulation causes intractable constitutional problems. ${ }^{38} \mathrm{He}$ dismissed the argument that SLRB jurisdiction would compel the Church to bargain over management topics implicating religious policy, ${ }^{37}$ noting that from 1969 to 1980 the Archdiocese and the faculty union had confined negotiations to secular employment terms. ${ }^{38}$ Furthermore, this case concerned the first unfair labor proceeding in fourteen years, ${ }^{39}$ indicating a history of cooperation.

In light of these facts, the Second Circuit disposed of the Church's two

27. Id. at 500-01.

28. Id. at 504-07.

29. The traditional standard is that "Congress intended to and did vest in the Board the fullest jurisdictional breadth constitutionally permissible under the Commerce Glause." NLRB v. Reliance Fuel Oil Corp., 371 U.S. 224, 226 (1963) (per curiam).

30. 440 U.S. at 508-10 (Brennan, J., dissenting) (citing Machinists v. Street, 367 U.S. 740, 749-50 (1961) (interpretation must be "reasonable" and "fairly possible")).

31. 440 U.S. at $511-16$.

32. Id. at $518 \mathrm{n} .11$. This issue is discussed infra notes 151-54.

33. 753 F.2d 1161 (2d Cir. 1985). This decision is criticized in Comment, The Constitutionality of State Labor Relations Board Jurisdiction Over Parochial Schools: Catholic High School Association v. Culveri, 30 CATH. LAW. 162 (1986).

34. The union filed unfair labor practice charges against the Archdiocese of New York for suspending 226 teachers who had protested the Church's attempt to change the substitution policy in violation of the collective bargaining agreement. 753 F.2d at 1163-64.

35. 753 F.2d at 1163, 1171 (ciling 1968 N.Y. Laws ch. 890, at 2389 (amending State Labor Relations Act, N.Y. LAB. LAW $\$ 715$ (McKinney 1968))). The State Labor Board was not preempted, because after Catholic Bishop the NLRB retained no jurisdiction over this employer. 753 F.2d at 1165 n.2.

36. Id. at 1163-69. See NLRB v. Catholic Bishop, 440 U.S. 490, 501-04 (1979) (foreseeing no escape from serious constitutional difficulties).

37. 753 F.2d at 1167.

38. These limitations were reflected in collective bargaining agreement clauses entrusting all religious functions to the Church. Id. at 1163.

39. Id. at 1165 . 
religion clause defenses. The court first decided that the Board's role-limited to ordering the diocese to bargain over secular subjects ${ }^{40}$ and to processing unfair labor practice charges that required no investigation of religious doctrine" entanglement" necessary for an establishment clause violation. ${ }^{12}$ The court then held that the compelling state interest in enforcing labor laws justified any incidental burdens on the clergy's free exercise rights. ${ }^{43}$

Judge Cardamone's focus on the factual history of parochial school labor relations and his attempt to reconcile competing interests departed from prior judicial approaches, which had accepted the Church's hypothetical arguments and therefore rejected the feasibility of accommodation. This Note adopts Catholic High School's general methodology and conclusions, but corrects two flaws in its First Amendment analysis. First, the Second Circuit confused the central issue-free exercise "burden" on Church autonomy in operating its schools-with establishment clause "entanglement." 44 Reliance on the latter is misplaced because uniform application of labor acts to all private schools does not "establish" (i.e., publicly support) religion. ${ }^{45}$ Second, the court oversimplified the free exercise problem by deeming the degree of infringement slight because compliance with labor acts did not contravene Catholic doctrine, which champions workers' rights. ${ }^{48}$ The Second Circuit thus failed to address fully the dispositive question of whether labor statutes interfered with the Catholic educational mission-transmitting religious values. ${ }^{47}$

\section{Future Conflict and Probable Supreme Court Intervention}

Catholic High School was not appealed to the Supreme Court, yet the decision foreshadows conflict. Eighteen states-including many with a

40. Id. at 1167. Also, the Board cannot compel agreement over specific contract terms. Id.

41. Id. at 1168-69. For example, in an illegal discharge claim, the Board could proceed only where a teacher would not have been fired "but for" anti-union animus. Id. (citing NLRB v. Transportation Management Corp., 462 U.S. 393 (1983) (discussed infra text accompanying note 144)).

42. 753 F.2d at 1166-69.

43. Reasoning that the SLRB did not infringe the Church's absolute freedom to hold religious beliefs but rather regulated conduct, the court compared labor laws to other constitutionally permissible exercises of the police power (e.g., state testing of teachers). Id. at 1169-71.

44. See id. at 1166-69.

45. This Note adopts Laycock's argument that an establishment violation must involve state assistance to religion, and that the establishment clause therefore does not apply to parochial school labor relations. For further explanation, see infra note 104.

46. 753 F.2d at 1170 , citing Kryvoruka, supra note 6, at 52 n.74 (noting Church's historically staunch support of unions). This analysis ignores the Bishops' free exercise right to pursue Catholic labor goals (e.g., justice for workers) independent of state-dictated methods, even though government labor laws and Catholic ideology may share certain aims. See Laycock, supra note 6, at 1399. Catholic High School invoked Cap Santa Vue, Inc. v. NLRB, 424 F.2d 883, 886-89 (D.C. Cir. 1970), for the proposition that the NLRA does not compel "belieP" in collective bargaining. 753 F.2d at 1170 . The question, however, is not whether a law demands belief, but whether a neutral statute as applied infringes free exercise rights.

47. Also, while commending the SLRB's restraint, the court did not place explicit limits on Board power in order to ensure future non-interference. 
large number of parochial schools-have labor acts; ${ }^{48}$ all but one have been construed to encompass every employer not specifically exempted. ${ }^{40}$ The state statutes that cover nonprofit or religious organizations are not subject to the preemption doctrine, which applies only to provisions identical to those in federal acts. ${ }^{50}$ Currently, only New York and Hawaii labor boards regulate Catholic schools, ${ }^{\text {,1 }}$ but other states seem likely to follow. ${ }^{\text {s2 }}$ Churches will continue to raise First Amendment defenses, with inconsistent results. Circuit court conflict $^{\text {ss }}$ will eventually require the Supreme Court to resolve the constitutional question left open in Catholic Bishop. ${ }^{54}$

48. Labor relations acts in states with many Catholic schools include: CoNN. GEN. STAT. §§ 31101 to -111b (1985); Mass. Gen. Laws ANN. ch. 150A, \$§ 1-12 (West 1982 \& Supp. 1987); Mich. Comp. Laws ANN. $\$ \S 423.1-.30$ (West 1978 \& Supp. 1987); N.J. STAt. ANN. §§ 34:13A-1 to -14 (West Supp. 1987); N.Y. Lab. LaW §§ 700-717 (McKinney 1977); PA. Stat. ANN. tit. 43, §§ 211.1-.13 (Purdon 1987); R.I. Gr.N. LAws $\S \S 28-7-1$ to -7-47 (1986); and WIs. STAT. ANN. §§ $111.01-19$ (West 1974 \& Supp. 1986).

For other state labor acts, see Col.o. Rkv. STAT. \$§ 8-3-101 to -123 (1986); HAw. Rev. STAT. §§ 377-1 to -18 (1976 \& Supp. 1980); KAN. Strat. ANN. $\$ \S 44-801$ to -817 (1986); Minn. STAT. ANN. $\$ \S 179.01-.17$ (West 1966 \& Supp. 1987); N.D. CE.NT. CoDF $\$ \S 34-12-01$ to -12-14 (1980 \& Supp. 1985); Or. Rkv. STAT. $§ \S 663.005-.295$ (1985); S.D. Codified Laws ANN. $\S \S 60-9 A-1$ to -15 (Michie 1978 \& Supp. 1987); Urah ConE. ANN. §§ 34-20-1 to-13 (1974 \& Supp. 1987); VT. STAT. ANN. tit. 21, §§ 1501-1623 (1978); W. VA. CoDE §§ 21-1A-1 to -8 (Michie 1985).

49. For the lone exception, see In Re Salvation Army, 349 Pa. 105, 36 A.2d 479 (1944) (construing Pennsylvania Labor Relations Act as not extending to nonindustrial, nonprofit employers). Other statutes have been interpreted to include nonprofit institutions. See, e.g., Industrial Comm'n v. Wallace Village for Children, 165 Colo. 10, 437 P.2d 62 (1968); Success Village Apts., Inc. v. Local 376, UAW, 175 Conn. 165, 397 A.2d 85 (1978); Kelley v. Day Care Center, 141 Vt. 608, 451 A.2d 1106 (1982); Wisconsin Employment Relations Bd. v. Evangelical Deaconess Soc'y, 242 Wis. 78, 7 N.W.2d 590 (1943). See also In re Our Lady Queen of Angels Church, M.L.M.B. Case No. R66 C-156 (1966) (construing Michigan Labor Mediation Act as covering certain church employees).

50. See supra notes 2 \& 35. See also Christ the King Regional High School v. Culvert, 815 F.2d 219, 222 (2d Cir. 1987) (since NLRB retains no jurisdiction over Catholic school employer, state labor board remains free to regulate).

51. For discussion of New York's regulation, see supra notes $33-43$ and accompanying text. See also Roman Catholic Church, Case No. 37-RC-2081, NLRB Region 537, Honolulu, Hawaii (filed July 18, 1975). When the NLRB withdrew, the Hawaii state board filled the vacuum. Pfeffer, supra note 6 , at 284 .

52. See supra note 49.

53. Indeed, intra-circuit conflict has appeared on these issues. In Universidad Central de Bayamon v. NLRB, 793 F.2d 383 (1st Cir. 1986) (en banc), the court deadlocked 3-3 over extending Catholic Bishop to universities; as a result, the Board's request for enforcement of a collective bargaining order was denied. Three judges argued that Catholic Bishop's reasoning was inapplicable because college professors inculcate religious values to a much lesser degree than do Catholic elementary and secondary school teachers. Id. at 383-91, 403-06. They cited Catholic High School for the proposition that labor boards play a limited role requiring no intrusion into religion. Id. at 388,406 . For further discussion, see Case Comment, 62 Notre: Dame. L. Rev. 255 (1987).

54. See NLRB v. Catholic Bishop, 440 U.S. 504, 507 (1979). In resolving this issue, the Court should follow established principles of federalism by deferring to a state labor boand, unless the Church provides concrete evidence of a free exercise injury. See Ohio Civil Rights Comm'n v. Dayton Christian Schools, Inc., 106 S. Ct. 2718 (1986) (reversing federal court injunction of state commission's investigation of sex discrimination claim filed by discharged sectarian school teacher, provided that church had opportunity to litigate First Amendment claims during and after proceedings).

Decisions affecting Catholic schools also have important practical ramifications, since the Church runs America's largest private educational system, as described supra note 1 . See, e.g., Committee for Pub. Educ. v. Nyquist, 413 U.S. 756, 773, 795 (1973) (denying state aid might exacerbate financial plight of parochial schools, thereby causing crisis in public education). 


\section{The Religious and Historical Context of Parochial SCHOOL LABOR RELATIONS}

The judicial rift begun by Catholic High School underscores the need for a fresh approach which nonetheless comports with the Supreme Court's free exercise jurisprudence. When individuals or institutions demand exemption from regulation on religious grounds, the Court's threshold task is to determine whether their allegations have a realistic foundation in a church's doctrine and customs ${ }^{65}$ - an inquiry designed to detect feigned $^{58}$ or speculative claims. ${ }^{57}$ Where a petitioner establishes that application of a law "burdens" a sincere ${ }^{88}$ belief vital to his religion, the state must prove that the regulation serves a "compelling" interest." For example, in Wisconsin v. Yoder, ${ }^{60}$ the Court examined the theology and history of the Amish Church, concluding that enforcement of a compulsory school attendance statute would violate the "central," "fundamental" Amish belief that secular education past eighth grade contaminates children $^{61}$ and would threaten the intensely religious, agrarian Amish lifestyle. ${ }^{62}$ Yoder remains the only case where the Court has found free exercise hardship to be so extreme as to compel invalidation of a general

55. See Wisconsin v. Yoder, 406 U.S. 205, 210-19 (1972), discussed infra notes 60-62 and accompanying text. Cf. Serbian E. Orthodox Diocese v. Milivojevich, 426 U.S. 696 (1976) (examining Church's diocesan structure, law, and history to conclude that secular courts cannot review decisions of highest ecclesiastical tribunal).

56. The free exercise clause mandates judicial deference to religion. See, e.g., United States v. Ballard, 322 U.S. 78, 87 (1944) (tribunals "forbidden" from analyzing "truth" of individual religious beliefs); Serbian Diocese, 426 U.S. at 713 (yiclding to institutional authorities' interpretation of doctrine). Because claimants could exploit such deference, however, courts inevitably must ascertain whether a belief or practice is "religious." Thomas v. Review Bd., 450 U.S. 707, 713-14 (1981).

57. See, e.g., Presiding Bishop v. Amos, 107 S. Ct. 2862, 2874 (1987) (O'Connor, J., concurring) ("there must in fact be an identifiable burden on the exercise of religion"); Tony \& Susan Alamo Found. v. Secretary of Labor, 471 U.S. 290, 303 (1985) (claimant must show government program "actually burdens" religious beliefs). Cf. Associated Press v. NLRB, 301 U.S. 103, 131-32 (1937) (applying NLRA despite employer's First Amendment free press objections, because alleged injury "mere conjecture").

58. See United States v. Seeger, 380 U.S. 163, 184-85 (1965) (draft board may question sincerity of religious claim for military exemption).

59. See Sherbert v. Verner, 374 U.S. 398, 402-07 (1963) (formulating strict scrutiny test).

60. 406 U.S. 205 (1972).

61. Id. at $210-19$.

62. An exemption was granted only because the claimant "convincingly demonstrated," by reference to "a history of three centuries," the sincerity of his religious belief and the hazards of state enforcement to the survival of the Amish faith; the Court emphasized that "few other religious groups" could make such a showing. Id. at 234-36.

Unlike religions that stress worldly detachment, Catholicism links spiritual ideals to the secular community. See Pastoral Constitution on the Church in the Modern World, in The Documents of VAricin II 199 (W. Abbott ed. 1966) [hereinafter Documenrs]. The Church's labor advocacy and philosophy of integrated (temporal-religious) education illustrate this approach. See infra notes 66-74 and accompanying text. This commitment to societal involvement suggests that compliance with labor laws will affect Catholic enterprises less seriously than other religious employers-especially those who believe that unionism is evil per se. See Cap Santa Vue, Inc. v. NLRB, 424 F.2d 883 (D.C. Cir. 1970) (enforcing $\Lambda$ ct against Seventh Day $\Lambda$ dventist employer whose religion condemns unions). Compulsory board jurisdiction will, however, infringe Church freedom to pursue a labor policy according to its interpretation of Catholic labor doctrine. See supra note 46. 
regulatory law; three other claimants have prevailed in the specific context of unemployment compensation statutes applied to deny them benefits because they followed their beliefs. ${ }^{63}$ Using a modified Yoder methodology, ${ }^{64}$ this Note analyzes relevant Catholic doctrine and the history of lay teachers' unions to evaluate the allegations of some Church leaders that labor board jurisdiction will undermine ecclesiastical authority over education. ${ }^{6 s}$ While perhaps sincerely advanced, such claims are unsupported by empirical data. Indeed, the existing pattern in many dioceses-combining collective bargaining over compensation with Church autonomy over religious issues-should continue as long as labor boards confine their inquiry to secular matters.

\section{A. Catholic Labor and Education Doctrines and the Development of Parochial School Teachers' Unions}

Historically, the Catholic Church in the United States adapted the Vatican's pro-labor ideology ${ }^{68}$ to achieve practical ends, helping Catholic immigrants find protection in labor organizations. ${ }^{67}$ In the twentieth century, social changes wrought by world wars and depression brought redoubled Catholic efforts to ameliorate the plight of workers. ${ }^{68}$ American Catholics also continued the Church's traditional educational mission. ${ }^{69}$ An independent school system flourished, serving the large immigrant community at low cost. ${ }^{70}$ Schools were staffed by nuns and priests vowed to poverty and obedience-ensuring an inexpensive and compliant labor supply. ${ }^{\mathbf{7 1}}$

The Second Vatican Council (1962-65)-reaffirming the importance of

63. Sherbert v. Verner, 374 U.S. 398 (1963) (Seventh Day Adventist who refused to work on Sabbath); Hobbie v. Unemployment Appeals Comm'n, 107 S. Ct. 1046 (1987) (same); Thomas v. Review Bd., 450 U.S. 707 (1981) (Jehovah's Witness fired for rejecting transfer to plant's munitions department).

64. $\Lambda$ strict Yoder approach-investigating church doctrine and history to distinguish core from peripheral religious values-presents a grave danger: substituting judicial determination of the "centrality" of a belief for the judgment of church authorities. This Note suggests that courts conduct a doctrinal/historical inquiry only to provide a background against which to evaluate Church claims on a case-by-case basis. In the parochial school context, judges must focus not on determining the centrality of religious education to Catholicism, but rather on evaluating evidence concerning the effect of labor laws on the educational mission.

65. See, e.g., Caulfield v. Hirsch, 95 L.R.R.M. 3164, 3176-77 (E.D. Pa. 1977) (Board will force bargaining over religious curriculum and moral/spiritual conduct expected of teachers).

66. See Popr: Lfo XII, Rr:Rum Novarum (1893) (encyclical urging humane treatment of laborers and encouraging formation of unions).

67. See J. Et.l.1s, Documints of Amkrician Cathol.ic: History 611-29 (1956) (describing . Church service to immigrants and historical solidarity with unions).

68. See, e.g., POPE: PIUS X, QUAdRegesimo ANNo (1931) (encyclical expressing special concern for workers); M. PieHi., BRfakin(; BREAD 118-33 (1982) (discussing Depression-era picketing, boycotts, and strikes by radical Catholic Worker Movement).

69. See 1983 Conk: c.796-806 (canon law mandates religious education).

70. See Trabold, Educating the Immigrants: A Challenging Catholic Experiment, 13 MiGRATION TODAY 43 (1985).

71. Nationat. Conf. of Cathotit: Bishops, Economic: Justice for All: A Pastoral LetTER on Catholic: Social. Traching and the U.S. Economy 174-75 (1986) (hercinafter EcoNOMIC. Justtc:] (acknowledging religious teachers' sacrifices). 
religious education, ${ }^{72}$ stressing social justice, ${ }^{73}$ and encouraging popular participation ${ }^{74}$ - and the subsequent dramatic decrease in religious vocations $^{23}$ transformed American Catholic education. As lay people replaced nuns as the principal source of teachers, ${ }^{76}$ questions arose concerning the Church's commitment to applying its labor doctrine to its own workers. Simultaneously, rising public school teacher militancy restructured secular education. ${ }^{77}$ Labor acts were applied to teachers, ${ }^{78}$ who gained an unprecedented share of participation in management decisions. ${ }^{79}$

The combination of burgeoning Catholic school lay faculties and successful public educational unions catalyzed formation of parochial school teacher associations. ${ }^{80}$ The Catholic hierarchy's reaction to unionization ranged from encouragement to grudging acceptance to rejection. ${ }^{81}$ Some Church leaders justified disregarding Catholic pro-labor doctrine as necessary to preserve both episcopal authority and the financial health of Cath-

72. Declaration on Christian Education, in DocumEnrs, supra note 62, at 637-51. See also National. Conf. of Catrol.te: Bishops, To Trach As Jesus Did (1972) (religious faith informs all learning).

73. Pastoral Constitution on the Church in the Modern World, in Documents, supra note 62, at 199-308 (focusing on duty to help exploited social groups, including workers).

74. Decree on the Apostolate of the Laity, in Documenrs, supra note 62, at 489-521.

75. See Kerkhofs, Vatican II-Twenty Years On, 102 Pro Mundi VrrA 1, 23-32 (1985) (between 1964-1983, about 45,000 left priesthood, and seminary enrollment shrank; number of sisters has also "fallen sharply").

76. See National. Catholtc: Educ. Ass'n, Unitro States Catholic Elementary Schools And Their Financess 1-2 (1986) [hereinafter Elementary Schools] (current 80:20 ratio of lay to religious faculty reverses pre-Vatican II percentages).

77. S. Col.s, The. Unionization of Trachers 3-10 (1969) (describing American Federation of Teachers' militant tactics in early 1960's); M. MOskow, Teachers and UnIons 2-5 (1966) (same).

78. Many states have separate labor acts for teachers. See, e.g., Teacher Negotiation Act of 1965, Conn. Gin. Star. §§ 10-153a-n (1985).

79. C. Perry \& W. Wil.dman, The. Impactr of Nggotiations in Public. Education 139-89 (1970) (teachers' unions negotiate many policy matters, including curriculum, grading, extracurricular activities, and class size). In contrast, employee participation in industrial management is rare. See NLRB v. Wooster Div. of Borg-Warner Corp., 356 U.S. 342 (1958) (construing NLRA \& 8(d) as requiring "good faith bargaining" over "mandatory" subjects such as salaries, benefits, and working conditions, but not over "permissive" management issues).

80. However, lay teachers adopted a unique bargaining model that reflected the separate evolution of Catholic education. Unions limited negotiations to "bread and butter" issues and deferred to exclusive clerical control over all decisions implicating religious policy. See Kryvoruka, supra note 6, at 71-74 (management topics linked to religion are outside scope of "mandatory" bargaining).

81. For example, the Philadelphia Archdiocese has bargained voluntarily with a lay teachers' union since 1969. See Comment, Free Exercise, supra note 6, at 646-47; Kryvoruka, supra note 6, at 34 n.9. Similarly, Hartford has negotiated eight bargaining agreements with a teachers' association since 1965. Interview with Fr. James Fanelli, Superintendent of Hartford Archdiocesan High Schools ( $\Lambda$ pr. 21, 1986) [hercinafter Fanelli Interview]. In contrast, the Chicago Archdiocese immediately opposed teachers' unions. See NLRB v. Catholic Bishop, 440 U.S. 490 (1979). A hostile relationship also developed in Brooklyn. See cases listed supra note 13 for details of disputes.

Officially, Church leaders adopted a compromise position: they recognized the right of teachers to form unions and bargain collectively, but demanded respect for the "special character" of Catholic schools as faith communities devoted to religious and moral values. U.S. Catholic Conf. Subcomm. on Teacher Organizations, Teachers Unions In Catholic Schools, 7 Origins 225, 227-29 (1977). The Church stated that "the role of the government in monitoring the civil aspects [of labor relations] . . . is capable ultimately of a solution which will be satisfactory to all concerned parties." Id. at 229. 
olic education ${ }^{82}$ creating the impression that compliance with labor acts would have disastrous consequences.

\section{B. The Results of Parochial School Unionization}

The actual process and impact of collective bargaining in parochial schools indicate the possibility of coexistence. Since the mid-1960's, twenty-seven dioceses have negotiated with teachers' associations. ${ }^{83}$ Catholic schools in New York and Hawaii ${ }^{\text {84 }}$ have experienced compulsory labor board regulation. The results of unionization refute the myths that bargaining inevitably causes spiritual and economic chaos and that enforcement of labor acts entails insoluble constitutional difficulties.

Diocesan collective bargaining illustrates the feasibility of separating "mandatory" secular topics (e.g., salaries and benefits) from "permissive" religious issues. ${ }^{85}$ In fact, the National Association of Gatholic School Teachers, which represents many unions, insists on inclusion in bargaining agreements of broad "management rights" clauses guaranteeing the hierarchy's freedom to operate schools according to Catholic principles and removing all matters of faith from arbitration and the unfair labor practice process. ${ }^{86}$ Such respect for ecclesiastical prerogatives was displayed by the NLRB during the mid-1970's ${ }^{87}$ and has been maintained by state labor boards. ${ }^{88}$ This crucial insight has escaped the notice of many judges, who have assumed that the public school model of negotiating policy matters would be applied to church-operated schools. ${ }^{89}$

82. See, e.g., Catholic Bishop v. NLRB, 559 F.2d 1112, 1123, 1130-31 (7th Cir. 1977) (collective bargaining erodes Bishop's authority and threatens economic stability of Catholic schools), affd, 440 U.S. 490 (1979).

83. Interview with John Reilly, President of the National Association of Catholic School Teachers (Feb. 5, 1987) [hereinafter Reilly Interview]. Most of these dioceses bargain voluntarily, perhaps suggesting that Catholic leaders object not to unions per se, but rather to labor board oversight with "attendant costs in money, effort, and policy sacrifices." Bastress, supra note 6, at 338-39. However, this argument has two defects. First, it fails to explain why most dioceses have discouraged any teachers' organizations. See Nar'i. Cathoi.lc: Educ. Ass'N, Catholic High Schools and Their FiNANCES 8 (1986) [hereinafter HI(:H Sc:HoOts] and S.F. Examiner, Nov. 20, 1986, at A3, col. 1 (NCE $\Lambda$ estimates that although $23 \%$ of teachers are represented by some group, only $2 \%$ belong to true unions). Second, it exaggerates the negative impact of regulation by assuming that boards force negotiations over religious policy and implies that any law causing the Church economic loss or inconvenience is invalid. See infra notes 85-90.

84. See supra note 51 .

85. See, e.g., Agreement Between the Archdiocese of Hartford and the Hartford Catholic Education Association, July 1, 1983-June 30, 1986, at 5-6 [hereinafter Agreement] (diocese retains "exclusive right" to manage Catholic schools in all aspects-including curriculum, budget, personnel, and enrollment). See also diocesan collective bargaining agreements on file at the National Association of Catholic School Teachers Office in Philadelphia.

86. Reilly Interview, supra note 83. See Kryvoruka, supra note 6, at 82-83 (NLRB must recognize "managemental prerogative" in which employer's religious interests are protected absolutely).

87. Examination of NLRB and federal cases reveals no Board attempts to force negotiations over management issues enmeshed with religion. See supra Section 1.

88. See, e.g., Catholic High Scinool Ass'n v. Culvert, 753 F.2d 1161, 1163 n.1 (1985) (Archdiocesan agreement limited to secular issues, reserving religious functions to Church control).

89. Lacking any record evidence to support the conclusion that labor boards interfere with religious policy in elementary and secondary church schools, courts have incorporated irrelevant stud- 
Parochial school labor relations have been generally peaceful. Indeed, in some dioceses unionization has helped to reduce tension by clarifying the respective roles of priests and teachers and by identifying the goals of Catholic education. ${ }^{90}$ Unfair labor practices are uncommon. For example, Catholic High School represented the first litigation arising out of a bargaining relationship that had begun in $19699^{91}$ in Philadelphia, ten years elapsed between the advent of unionism and the first arbitration. ${ }^{92}$ Similarly, unions have rarely used pressure tactics: only a handful of strikes have occurred, and all were quickly settled.93 Where low salaries and poor working conditions have caused lay faculty unrest, denying labor board jurisdiction will exacerbate, not eliminate, dissatisfaction.

Finally, the Church has never established a correlation between lay teacher collective bargaining and Catholic school fiscal instability. ${ }^{94}$ Multiple factors unrelated to unionization (particularly demographic changes) explain the financial problems that plague parochial schools. ${ }^{95}$ Further-

ies detailing the transmutation of management issues (c.g., academic standards) into mandatory bargaining topics in public colleges-most frequently Brown, Collective Bargaining in Higher Education, 67 Mich. L. Rkv. 1067, 1075 (1969). See, e.g., Caulfield v. Hirsch, 95 L.R.R.M. 3164, 3176-77 (E.D. Pa. 1977) (certified union will expand bargaining subjects to include religious issues); Catholic Bishop v. NLRB, 559 F.2d 1112, 1124 (7th Cir. 1977), affd, 440 U.S. 490, 502-03 (1979). See also Bastress, supra note 6, at 324-30; Durso \& Brice, supra note 6, at 307-09; Laycock, supra note 6, at 1399; Comment, supra note 33, at 174-75; Comment, Free Exercise, supra note 6, at 658-60. Such assumptions ignore the distinctive bargaining history between Catholic schools and teachers' unions, who have always treated management issues regarding religion as non-negotiable. See supra note 80. See also Catholic High School, 753 F.2d at 1167-68 (rejecting applicability of public school studies). See generally Note, Religion Clauses, supra note 6, at 279-80 (criticizing judicial use of extrinsic literature to avoid case facts).

90. For example, Hartford's contract contains a preface outlining the mission of Catholic schools, and states that teachers "are expected to conduct themselves . . . in a manner consistent with the academic, social, moral and religious teachings of the Catholic Church." Agreement, supra note 85, at 1-4 (preface); id. at 7 (quote).

91. 753 F.2d 1161, 1163 (2d Cir. 1985).

92. Reilly Interview, supra note 83. Many grievances are referred to arbitration-private dispute resolution which involves no government interference. Kryvoruka, supra note 6, at 66-71.

93. For example, Hartford has never experienced a strike. Fanelli Interview, supra note 81 . In 1971, teachers in San Francisco and New York walked out. See Boles, Persistent Problems of Church, State, and Education, 1 J.L. \& Enuc. 601, 605 (1972). The only other dioceses where strikes have occurred are Pittsburgh and Philadelphia. See Pittsburgh Press, Sept. 11, 1985, at A12, col. 1; Philadelphia Inquirer, May 5, 1985.

94. Indeed, official Catholic school financial statistics reflect imprecise estimates. See ELEMENTARY Sc:Hools, supra note 76, at 3-5; High Schoots, supra note 83, at 2. Although these figures reveal budget difficulties nationwide, dioceses that bargain collectively have no greater problems than dinceses that unilaterally impose contract terms. Id. See also Kryvoruka, supra note 6, at 57 n.100 ("parochial schools that have complied with orders to bargain have experienced .. . no economic collapse"). The absence of any connection between unionization and fiscal soundness does not reflect the greater willingness of financially healthy dioceses to accept labor organizations. On the contrary, wealthy dioceses (c.g., Chicago) led the anti-union fight. See J. Got.t.In, supra note 18, at 280 (Chicago is America's richest diocese, with assets of $\$ 610$ million).

95. See genetally $\Lambda$. Greit.ty, W. MCGready \& K. MCCourt, Catholic Schools in a Decl.ining; Church 7-11 (1976) (discussing reduced family size among Catholics and corresponding decline in school enrollment); id. at 40-75 (movement of Catholics from ethnic city neighborhoods to suburbs lacking parochial schools); id. at 230-62 (decreased collections). See also J. Gollin, supra note 18, at 390-92 (attributing financial problems partly to mismanagement); A. GreELEY, ThE AMERICAN Cathol.J: 169-71 (1977) (same).

Admittedly, the shift to lay faculty has contributed to budget problems. See Higr Schools, supra 
more, common sense dictates that teachers understand the economic situation $^{98}$ and wish to preserve Catholic schools-and their jobs. ${ }^{97}$

Responding to post-Vatican II realities, American bishops in 1986 endorsed a cooperative, financially responsible approach to negotiations. ${ }^{98}$ The hierarchy acknowledged past failures in applying Catholic labor teachings to Church institutions" and pledged to "fully recognize the rights of employees to organize and bargain collectively." Although not legally binding, this moral commitment may signal a new era in parochial school employment relations and foreclose challenges to labor laws. ${ }^{101}$

In short, compliance with labor relations acts may require some adjustments, but need not sacrifice the clergy's First Amendment right to control all religious matters in parochial schools. ${ }^{102}$

\section{Constitutional Re-Analysis}

These overlooked doctrinal and historical factors necessitate a constitutional reevaluation of prior decisions. Courts have weakened their First Amendment analyses by applying establishment clause rules prohibiting "entanglement"103_relevant when state agencies implement statutes designed to aid religion-to parochial school labor relations cases, which more properly turn on the free exercise issue of government "burdens" on religion resulting from enforcement of impartial regulatory laws. ${ }^{104}$

note 83 , at 5-6 (lay teachers average $\$ 7000$ more in annual compensation than their religious counterparts). Nevertheless, these costs have arisen independent of union influence. See supra note 83 (98\% of Catholic teachers not unionized). Moreover, represented high school faculty earn $\$ 21,164$ in salary and benefits-only $10 \%$ more than non-organized teachers. See High ScHools, supra note 83, at 8. Finally, even if labor board jurisdiction were to cause increases in remuneration, such economic factors would not affect analysis of the constitutionality of labor relations acts. See infra note 140.

96. Indeed, the Philadelphia lay teachers' union in 1982 helped form "Business Leadership Organized for Catholic Schools," which has raised $\$ 30$ million. Reilly Interview, supra note 83. See Gary, Business Joins Education in Support of Catholic Schools, 16 Momentum 41 (1985).

97. Faith inspires many teachers to serve the Church. Lemon v. Kurtzman, 403 U.S. 602, 618-19 (1971). Others work in parochial schools because of the tight public school job market. See Comment, Labor Relations, supra note 6, at 1112; Catholic Bishop v. NLRB, 559 F.2d 1112, 1130 (7th Cir. 1977) (many teachers "[not] altogether motivated in secking employment by the love of the institution"), aff d, 440 U.S. 490 (1979). Neither faculty group is likely to wish to destroy parochial schools.

98. See Economic: Jusite:, supra note 71, at 174-76.

99. Id. at $174-75$.

100. Id. at 176 .

101. See id. at 54 (advocating vigorous enforcement of labor laws). The Church cannot justify excluding itself from labor acts, unless an exemption is necessary to protect Catholic education.

102. See Note, Religion Clauses, supra note 6, at 283 (continued operation of Catholic schools with organized faculties indicates that unions do not destroy schools' religious purposes); Kryvoruka, supra note 6 , at 50 n.68 (same).

103. To survive establishment clause scrutiny, a law must have a secular purpose, must not have the "primary effect" of advancing or inhibiting religion, and must not foster "an excessive government entanglement with religion." " Lemon v. Kurtzman, 403 U.S. 602, 612-13 (1971), quoting Walz v. Tax Comm'n, 397 U.S. 664, 674 (1970).

104. Where free exercise rights are at stake, the Court shows less concern for establishment problems than in cases involving state aid to religion. Compare Wisconsin v. Yoder, 406 U.S. 205 (1972) (granting exception where religious beliefs conflict with regulation) with Lemon v. Kurtzman, 403 U.S. 602 (invalidating state salary supplements to church school teachers). Nonetheless, expansion of the establishment clause to include action that "inhibits" religion has created confusion. See 
Furthermore, in evaluating free exercise claims, judges have mechanically applied the Sherbert $v$. Verner ${ }^{105}$ paradigm (i.e., an individual denied statutory benefits for obeying her religious convictions) without questioning its relevance to Catholic school labor disputes, ${ }^{108}$ which involve different parties and issues. First, an institutional rather than individual claim is asserted: the Church's right to operate schools free from state interference. ${ }^{107}$ Second, unlike the unemployment compensation scheme voided in Sherbert, labor relations acts do not withhold government largesse from Catholic employers for adhering to their beliefs. ${ }^{108}$ On the contrary, the Church is requesting the special benefit of exemption from neutral labor laws; in analogous situations, the Court has refused to grant such privileges. ${ }^{109}$ Moreover, Sherbert's three part test-considering whether claims are religious or secular, whether state action "burdens" free exercise, and whether the government has a sufficiently "compelling

Lemon, 403 U.S. at 612. Since a government inhibition is also an infringement of free exercise, courts have mistakenly invoked the establishment clause to examine free exercise issues. See generally Laycock, supra note 6, at 1378-85. To illustrate, judges have applied establishment cases involving state support of Catholic schools to parochial school labor disputes. See, e.g., Catholic Bishop v. NLRB, 559 F.2d 1112, 1131 (7th Cir. 1977), affd, 440 U.S. 490, 501-02 (1979) (collapsing discussion of "entanglement" with analysis of free exercise "burdens" caused by enforcement of NLRA); Caulfield v. Hirsch, 95 L.R.R.M. 3164, 3178-79 (E.D. Pa. 1977) (same); Catholic High School Ass'n v. Culvert, 753 F.2d 1161, 1166-69 (2d Cir. 1985) (same). Commentators have continued this misguided "entanglement" analysis. See Durso \& Brice, supra note 6; Bastress, supra note 6, at 315-37; Note, Religion Clauses, supra note 6, at 269-72, 281-85;. Pfeffer, supra note 6, at 289-90.

The "entanglement" in the "parochaid" cases involved ongoing government surveillance of teachers to ensure state funds were not being used for sectarian purposes. See, e.g., Meek v. Pittenger, 421 U.S. 349, 369-72 (1975). Such intrusive monitoring is a far cry from the minimal interference caused by labor board jurisdiction. See Warner, supra note 6, at 478-91; Kryvoruka, supra note 6, at 46-47, 61-62. Moreover, statutes granting money to church schools are distinguishable from purely regulatory laws, even though statutory "neutrality" remains an elusive concept. See, e.g., Lemon at 613 (in subsidizing parochial schools, legislature pursued secular aim of enhancing quality of education).

105. 374 U.S. 398 (1963).

106. See, e.g., Catholic Bishop, 559 F.2d at 1124; Caulfield, 95 L.R.R.M. at 3178; Catholic High School, 753 F.2d at 1169-71.

107. This institutional "right to autonomy" recognizes that individuals usually exercise religion through churches, which deserve constitutional protection in defining and developing religious beliefs and practices. See Presiding Bishop v. Amos, 107 S. Ct. 2862, 2871 (1987) (Brennan, J., concurring) (citing Laycock, supra note 6, at 1389).

108. See supra note 63 (cases striking down unemployment compensation statutes). Sherbert recognized that a statute imposing an "indirect" financial burden, forcing one to forego religious practices (e.g., Sabbath observance) to obtain benefits, offends free exercise as much as a law that directly compels or prohibits religious conduct. 374 U.S. at 403-04. Sherbert does not inply, however, that any regulation which increases a church's costs is an unconstitutional "indirect burden." See infra notes 113-22 and accompanying text.

109. See United States v. Lee, 455 U.S. 252 (1982) (rejecting Amish religious objector's request for exemption from paying social security taxes); id. at 261-64 (Stevens, J., concurring) (while state must show compelling interest to justify "unequal treatment" of religious observers, burden of proof shifts to claimant who demands exemption from neutral, generally-applicable law). See also Bob Jones Univ. v. United States, 461 U.S. 574 (1983) (upholding IRS denial of tax-exempt status to religious college which sought exception from antidiscrimination laws on ground that their religion mandated certain forms of racial discrimination). 
interest"110 - has been inconsistently applied, reflecting the Court's desire to weigh more heavily legislative concerns. ${ }^{111}$

Balancing the Church's wish to prevent labor board intrusion against the state's interest in protecting employees' rights, this Note uses a flexible free exercise analysis which devises limiting principles that tailor board jurisdiction to accommodate First Amendment concerns. ${ }^{112}$

\section{A. Regulation of Parochial Schools and Their Teachers: The Church's General Claims}

The Church's argument that religious affiliation relieves a school employer of the duty to obey labor acts equates any government contact with unconstitutional interference and ignores already-pervasive regulation. ${ }^{113}$ Except for wholly spiritual practices like worship, freedom to act in exercise of beliefs is not absolute. ${ }^{114}$ Important but not purely religious areas like education may be regulated in their secular aspects. ${ }^{115}$ For example, under its police power, the government enforces fire, building, and zoning ordinances. ${ }^{118}$ Pursuant to educational codes, states accredit and inspect all schools, certify teachers, and implement attendance, calendar, and curriculum requirements ${ }^{117}$ - thereby imposing government educational preferences on church schools and directly influencing the process of transmit-

110. 374 U.S. at 403-07.

111. For example, the state interest in uniform administration of the social security system overrode an $\Lambda$ mish farmer's Yoder-like claim of free exercise interference. Lee, 455 U.S. 252 (1982). See also Gillette v. United States, 401 U.S. 437 (1971) (government interest in maintaining armed forces overcomes free exercise claim of conscientious objector); Goldman v. Weinberger, 475 U.S. 503 (1986) (military's need for uniformity sufficient reason to uphold regulation against indoor headgear over free exercise claim of Jew wearing yarmulke). Compare Bowen v. Roy, 106 S. Ct. 2147, 2153-58 (1986) (plurality opinion) (statute requiring provision of social security number to receive welfare benefits upheld as serving "legitimate public interest" even though it "indirectly and incidentally" forced choice between adhering to beliefs or obtaining benefits) with Hobbie v. Unemployment Appeals Comm'n, 107 S. Ct. 1046, 1048-50 (1987) (criticizing Roy and reaffirming "compelling state interest" scrutiny).

112. Cf. Comment, Free Exercise, supra note 6, at 662 (rejecting "tailoring" as too costly).

113. Kryvoruka, supra note 6 , at $48 \mathrm{n} .58$ (parochial schools subject to significant degree of state regulation which presupposes severance of religious from secular conduct). Such comprehensive supervision vitiates Laycock's argument that clergy might oppose labor board jurisdiction to avoid a precedent which could be used to justify regulation in other areas. Laycock, supra note 6, at 1398-99.

114. See Cantwell v. Connecticut, 310 U.S. 296, 303-04 (1940).

115. See Bagni, Discrimination in the Name of the Lord: A Critical Evaluation of Discrimination by Religious Organizations, 79 Colum. L. REv. 1514, 1539-49 (1979) (placing church schools midway between core spiritual practices (e.g., worship) which are immune from government regulation and purely secular enterprises (e.g., businesses) where regulation is acceptable).

Especially where the Church supplants a state institution, the government may implement uniform standards. See, e.g., Board of Educ. v. Allen, 392 U.S. 236, 245-48 (1968) (schools used to fulfill compulsory education laws may be required to meet state-imposed instructional criteria). Full-time church schools must be distinguished from supplementary religious programs offered for children who attend public schools. See Board of Jewish Educ., 210 N.L.R.B. 1037 (1974) (declining jurisdiction over such operations).

116. See Catholic High School Ass'n v. Culvert, 753 F.2d 1161, 1169-70 (2d Cir. 1985).

117. See supra note 115. See also Note, Religion Clauses, supra note 6, at 281-83 (detailing Catholic school compliance with Illinois scholastic regulations). 
ting religious faith. ${ }^{118}$ In the area of employment, administrative agencies ensure compliance with the Fair Labor Standards Act, ${ }^{119}$ Title VII, ${ }^{120}$ and payroll tax and deduction laws ${ }^{121}$ - thus increasing operating costs. Since the Catholic Church accepts this comprehensive regulation, labor board jurisdiction should be similarly unobjectionable. ${ }^{\mathbf{1 2 2}}$

The foregoing analysis reveals the myopia of Catholic Bishop's exclusive focus on a teacher's "unique role . . . in fulfilling the mission of a church-operated school."123 Existing government regulation implicitly acknowledges two other roles: as a substitute for a public school instructor and as an employee, a parochial school teacher is subject to ordinary educational and employment laws. Therefore, unless labor relations acts are peculiarly burdensome, they likewise should be enforced.

\section{B. Labor Relations Acts and Free Exercise Interference}

Labor acts, which expressly limit labor board jurisdiction and remedial power, ${ }^{124}$ seem less intrusive than other regulations imposed on schools. Boards intervene only at the request of employees who decide to exercise their right to organize and bargain collectively. ${ }^{125}$ Moreover, labor laws preserve managerial control over personnel and policy matters and prohibit only anti-union activities. ${ }^{128}$ Nevertheless, the potential for free exercise interference arises in applying particular statutory provisions-problems best foreclosed by restricting labor board discretion.

118. For a radical proposal, see Developments in the Law-Religion and the State: Government Regulation of Religious Organizations, 100 HARv. L. Rkv. 1740, 1757-58, 1777-78 (1987) (Church right to autonomy outweighs state interest in uniform educational standards, justifying exemption of parochial school curriculum, teachers, and operations from regulation).

119. 29 U.S.C. § 201 (1982). See Marshall v. Pacific Union Conf. of Seventh Day Adventists, No. CV-75-3032-R (C.D. Cal. Mar. 23, 1977) (FLSA applicable to Seventh Day Adventist schools).

120. Civil Rights $\Lambda$ ct of 1964,42 U.S.C. $\$ \S 2000 \mathrm{e}-1$ to -17 (1982). See EEOC v. Mississippi College, 626 F.2d 477, 486-89 (5th Cir. 1980) (application of Title VII's provisions proscribing racial and sexual discrimination to lay teachers at Baptist college did not interfere with school's religious mission), cert. denied, 453 U.S. 912 (1981). But cf. Presiding Bishop v. Amos, 107 S.Ct. 2862 (1987) (upholding constitutionality of Title VII exemption of church organizations from prohibition against religious discrimination in employment).

121. In general, tax laws are uniformly applied. See supra note 109 (discussing United States v. Lee, 455 U.S. 252 (1982)). But see St. Martin Evangelical Lutheran Church v. South Dakota, 451 U.S. 772 (1981) (exempting certain church schools from unemployment compensation taxes).

122. Courts have rejected attempts by Church employers to resist NLRB jurisdiction in every enterprise except parochial schools. See, e.g., Denver Post of the Nat'l Soc'y of Voluntecrs of Am. v. NLRB, 732 F.2d 769 (10th Cir. 1984) (Board may regulate religious organization that maintains chapels); Tressler Lutheran Home for Children v. NLRB, 677 F.2d 302 (3d Cir. 1982) (allowing NLRB jurisdiction over nursing home).

123. NLRB v. Catholic Bishop, 440 U.S. 490, 501 (1979).

124. Both the NLRA and state labor acts contain detailed provisions outlining the process by which labor boards exercise jurisdiction. See supra note 10 . Indeed, boards lack the power to enforce their own orders. See, e.g., NLRA, 29 U.S.C. $\S 159$ (d), $\$ 160(\mathrm{c})$-(g) (1982). Thus, if a labor board ever exceeded its bounds in issuing an order, a Catholic employer could refuse to comply and could raise religion clause defenses if the board requested judicial enforcement. See Catholic High School Ass'n v. Culvert, 753 F.2d 1161, 1167 (2d Cir. 1985).

125. See, e.g., 29 U.S.C. $\$ \S 157,159$ (1982).

126. See, e.g., id. \$ 158 (1982). 


\section{Labor Board Assertion of Jurisdiction}

Some Church leaders have opposed the threshold assertion of board jurisdiction $^{127}$ as curbing their freedom to supervise religious education. ${ }^{128}$ They raise two significant concerns. First, labor boards must avoid judgments regarding the relative religiousness of a school ${ }^{139}$-an inquiry which led the NLRB to conclude that Catholic schools are not "religious institutions."130 Instead, boards must adhere to neutral monetary yardsticks (e.g., revenue) in deciding whether to exercise jurisdiction. ${ }^{131}$ Second, boards must sacrifice their usual discretion to designate an appropriate bargaining unit. ${ }^{132}$ The NLRB often certified a multi-elementary school unit to maximize teacher bargaining clout, ignoring the fact that the Ghurch entrusts control over each elementary school to the local pastor ${ }^{135}$-in contrast to diocesan high schools under centralized episcopal administration. ${ }^{134}$ Labor boards must accept clerical decisions regarding the autonomy or interdependence of Catholic schools in each diocese and select bargaining units accordingly. ${ }^{135}$ With these restrictions, the mere assertion of jurisdiction over parochial school labor relations poses little threat to free exercise.

127. See, e.g., id. $\S 159$ (1982) (describing process of certifying union).

128. See, e.g., Catholic Bishop v. NLRB, 559 F.2d 1112, 1123, 1126 (7th Cir. 1977), affd, 440 U.S. 490 (1979); Caulrield v. Hirsch, 95 L.R.R.M. 3164, 3166, 3170, 3176 (E.D. Pà. 1977). The Church also argues that board jurisdiction will "chill" its exercise of religious rights. 559 F.2d at 1124; 95 L.R.R.M. at 3177-78; Bastress, supra note 6, at 328-29; Comment, Free Exercise, supra note 6, at 660-62. Because all regulation affects religious conduct somewhat, the potential for "chilling" alone is an insufficient reason to strike a statute. See Catholic High School Ass'n v. Culvert, 753 F.2d 1161, 1170-71 (2d Cir. 1985) (dismissing any "chilling effect" as incidental).

129. See supra notes $11-12,21$. This Note urges abandonment of the NLRB's "completely religious/religiously associated" test. But see Warner, supra note 6, at 501 (defending Board standard as avoiding entanglement); Kryvoruka, supra note 6, at 41-42, 46-49 (same).

130. Cardinal Timothy Manning, 223 N.L.R.B. 1218, 1218 (1976). See also Catholic Bishop, 440 U.S. at 502 (NLRB questioning clergy about school's religious activities infringes free exercise).

131. See supra note 10. Labor boards might shift their focus from the religious employer, considering instead whether an employee of a religious organization was hired from the public marketplace and whether he has a secular counterpart. Comment, A New Approach to NLRB Jurisdiction over the Employment Practices of Religious Institutions, 54 U. CHI. L. Rev. 243 (1987). Applied to parochial schools, this analysis would exclude from jurisdiction religion teachers but not math faculty. Id. at 273. This "employee activity" test, however, would embroil labor boards in classroom investigations - for example, whether a biology teacher addressing sexuality from a Catholic perspective has a secular counterpart. Furthermore, since the Church retains discretion to discipline a teacher who refuses to implement a religion program as ordered by Catholic authorities, distinctions among lay teachers are unnecessary, and also would fragment the union.

132. See, e.g., NLRA, 29 U.S.C. $\$ 159$ (b) (1982).

133. Such NLRB insensitivity led to the injunction in Caulfield v. Hirsch, 95 L.R.R.M. 3164 (E.D. Pa. 1977), discussed supra notes 17-19 and accompanying text. See Comment, Free Exercise, supra note 6, at 643-46 (describing Board aims in designating multi-school units and clergy's opposition). Collective bargaining in elementary schools remains rare.

134. Even so, some bishops object to a multi-high school bargaining unit. See Cardinal Timothy Manning, 223 N.L.R.B. 1218 (1976).

135. See Serbian E. Orthodox Diocese v. Milivojevich, 426 U.S. 696 (1976) (church tribunal, not secular court, must determine diocesan structure). 


\section{Processing Unfair Labor Practice Charges}

The possibility of unconstitutional infringement increases when unfair labor practice charges are filed: in ensuing adversarial procedures, a labor board's judgments may tread on religious freedoms. ${ }^{138}$ Nevertheless, boards can minimize interference by adapting their ordinary principles of restraint and by formalizing extant Gatholic school bargaining customs.

The Church contends that its refusal to discuss employment terms affecting religious policy will incur board sanctions for violation of the duty to bargain in good faith, ${ }^{137}$ based on the assumption that such matters are mandatory items of negotiation. ${ }^{138}$ However, doctrinal subjects are within the permissive "management rights" area. The alleged impossibility of separating secular from religious bargaining issues ${ }^{139}$ is belied by dozens of diocesan collective agreements that accomplish precisely this goal. ${ }^{\mathbf{1 4 0}}$ Labor boards can avoid conflict by maintaining this dichotomy and by following their usual practice of not interfering with negotiations over specific contract terms. ${ }^{141}$

Churches also fear that boards will assess the doctrinal validity of asserted religious defenses in "mixed motive" discharge cases. ${ }^{142}$ For example, the Catholic Bishop court posed the hypothetical of a school dismissing a pro-union teacher who also advocated a position "totally at odds with . . . [the] Catholic faith,"143 such as favoring abortion. A discriminatory discharge complaint in this situation could be resolved using established guidelines. In NLRB v. Transportation Management Corp., ${ }^{144}$ the

136. Warner, supra note 6 , at $474-75$.

137. See, e.g., NLRA, 29 U.S.C. $\$ 158$ (d) (1982). All state labor acts contain similar "good faith" bargaining provisions. See supra note 48 .

138. See supra text accompanying notes 85-89 (refuting this assumption).

139. Many courts have accepted the Church's claim that because parochial schools are "pervasively religious," all items of mandatory collective bargaining encompass religious issues. See, e.g., Caulfield v. Hirsch, 95 L.R.R.M. 3164, 3176-77 (E.D. Pa. 1977) (NLRB would have "insuperable task" of separating secular from religious subjects in ascertaining violation of duty to bargain); Catholic Bishop v. NLRB, 559 F.2d 1112, 1121-24 (7th Cir. 1977), affd, 440 U.S. 490 (1979).

140. See supra notes 85-88. Blurred areas of the "secular vs. religious" bargaining dichotomy might appear. For example, the "secular" issue of salaries could implicate financial stability, infringing the Church's basic free exercise right to operate schools. But see supra note 94 (statistics reveal no correlation between collective bargaining and budget difficulties). Even assuming the bishops could demonstrate that enforced bargaining had such an effect, this would simply indicate the hierarchy's failure to raise adequate funds. Constitutionally, it is less problematic for the government to insist that churches recover the expenses of running schools (including costs of compliance with regulations) from religious adherents than to exempt religious employers from laws. See infra note 151 and accompanying text (discussing this indirect "establishment"). Indeed, the Supreme Court has treated Church predictions of financial doom as legally irrelevant in the "parochaid" cases. See, e.g., Lemon v. Kurtzman, 403 U.S. 602, 625 (1971) (religion clauses mandate denial of state aid to parochial schools despite their economic plight).

141. See H.K. Porter Co. v. NLRB, 397 U.S. 99, 102 (1970) (Board cannot compel parties to agree on collective bargaining contractual details).

142. Boards must sometimes determine whether an employer's proffered reason for firing an employee is a pretext to punish union activity. See supra note 41 .

143. 559 F.2d at $1124-25$.

144. 462 U.S. 393 (1983). 
Supreme Court held that the NLRB must limit its inquiry to instances where "but for" anti-union animus, the employer would not have fired a worker. Applying this standard to parochial schools, Church proof of a doctrinal reason for discharge (e.g., pro-abortion teaching) would make any contributing anti-union motivation irrelevant and would foreclose inquiry into religious beliefs (e.g., Catholic pro-life theology). ${ }^{145}$

In sum, labor boards may regulate parochial schools by observing these constitutionally mandated limits: employing neutral jurisdictional standards, enforcing the duty to bargain over secular issues only, and prosecuting unmistakable unfair labor practices. Such modified application of labor acts reduces the Church's religious claim to an alleged right to avoid the inconvenience and expense of compliance-incidental hardships not triggering "compelling state interest" scrutiny. ${ }^{146}$ The government's interest in uniform enforcement of labor laws ${ }^{147}$ outweighs minor, primarily economic burdens on religious organizations. ${ }^{148}$

\section{Restricted Labor Board Jurisdiction: The Optimal Accommodation}

Certainly, the proffered restrictions on labor board conduct somewhat reduce the effectiveness of labor acts, amounting to a partial exemption for parochial school employers. Nevertheless, such sensitivity is necessary to protect free exercise religious liberty. ${ }^{149}$ This Note's proposal represents the optimal accommodation: it preserves employees' statutory rights, while preventing government intrusion into religious affairs. In contrast, the Catholic Bishop construction of the NLRA crafted a blanket exception ${ }^{150}$

145. $\Lambda$ more difficult case.involved a teacher who questioned church authority and disparaged the sacramentality of marriage, but who was not terminated until he became involved in union activities. The NLRB ruled that because the Catholic school had previously rehired this teacher despite incidents of disrespect, anti-union animus must have motivated the decision. Roman Catholic Diocese of Brooklyn, 222 N.L.R.B. 1052, 1056-57 (1976), enforced in part sub nom. Nazareth Regional High School v. NLRB, 549 F.2d 873. 882-83 (2d Cir. 1977) (ruling teacher's claim time barred). Under this Note's framework, the Church's religious reasons for dismissal would have been sufficient to preclude any inquiry into accompanying anti-union motives.

146. To activate such strict scrutiny, enforcement of a law must exert "substantial pressure" to modify behavior and to violate beliefs. Thomas v. Review Bd., 450 U.S. 707, 718 (1981).

147. This interest is especially strong in states where labor rights are constitutionally guaranteed. See, e.g., N.Y. Const. art. 1. \$17; N.J. Const. art. $1, \S 19$.

148. See Braunield v. Brown, 366 U.S. 599 (1961) (upholding Sunday closing law despite financial impact on Jewish merchants). See also supra notes 113-22 and accompanying text (discussing constitutional validity of cosily regulations). Even pro-Church commentators concede that free exercise centrally concerns the clergy's control over school management issues involving religion, not wages and benefits. See Laycock, supra note 6, at 1402.

149. See McDaniel v. Paty, 435 U.S. 618, 639 (1978) (Brennan, J., concurring) (accommodation strives to exempt from regulation individuals whose religious beliefs and practices would be infringed or "to create without state involvement an atmosphere in which voluntary religious exercise may flourish"). See also Walz v. Tax Comm'n, 397 U.S. 664 (1970) (approving property tax exemption for churches and other nonprofit institutions).

150. Also less than optimal is complete denial of protection for church employers. See, e.g., 1968 N.Y. Laws ch. 890, at 2389 (amending State Labor Relations Act, N.Y. LAB. LAws $§ 715$ (McKinney 1968) (extending coverage to religious employers without prescribing special labor board procedures). See infra note 155 . 
that destroyed these legislative guarantees without serving any additional purpose except to save Church employers the cost of obeying labor laws. This indirect aid, not "excessive entanglement," is the key establishment clause issue raised by parochial school labor relations cases. ${ }^{151}$ Because all attempts to accommodate free exercise in a sense "advance" religion, ${ }^{182}$ a partial rather than total exemption is always preferable ${ }^{253}$ when religious rights can be safeguarded through the less drastic alternative. ${ }^{154}$

Labor board exercise of jurisdiction with due respect for the religious prerogatives of Catholic school employers ${ }^{153}$ obviates the need for judicial intervention. Unlike legislatures, which may exceed the requirements of free exercise in accommodating religion, courts lack the power to carve exceptions into statutes promoting the general welfare ${ }^{\mathbf{1 5 8}}$ unless the free

151. NLRB v. Catholic Bishop, 440 U.S. 490,518 n.11 (1979) (Brennan, J., dissenting) (judicially created exception solely for church schools raises establishment clause question). See also Warner, supra note 6, at 482-84 (non-assertion of jurisdiction is a "special privilege" forbidden by establishment clause).

152. McConnell, Accommodation of Religion, 1985 SuP. Cr. Rrv. 1, 6.

153. This Note rejects the argument that even a successful board attempt to "reasonably accommodate" church schools constitutes favoritism violating the establishment clause, whereas wholesale exemption does not. Catholic Bishop v. NLRB, 559 F.2d 1112, 1128-31 (7th Cir. 1977), affd, 440 U.S. 490 (1979). See Casenote, 9 Skron Hal.r. L. Rev. 333, 355-57 (1978) (exclusion of parochial schools poses greater establishment problem than accommodation).

154. $\Lambda$ legislative full exemption, however, might survive establishment clause scrutiny. In Presiding Bishop v. Amos, the Supreme Court held that Congress' exemption of religious organizations engaged in secular, nonprofit activities from Title VII's prohibition against religion-based employment discrimination did not violate the establishment clause. $107 \mathrm{~S}$. Cl. 2862 (1987) (examining Civil Rights Act of 1964, Pub. L. No. 88-352, tit. 7, \$ 702, 785 Stat. 241, 266, as amended 1972 (current version at 42 U.S.C. $\$ 2000($ c)-1 (1982))). Justice White assumed the constitutional adequacy of Title VII's original exemption covering employees fulfilling a religious function (the type of accommodation this Note favors). Id. at 2868. Nonetheless, the Court noted that a tribunal's failure to perceive the religious significance of seemingly "secular" activities might interfere with a church's ability to carry out its religious mission. Therefore, the Court concluded, this amendment constituted "benevolent neutrality" permitted by the establishment clause and was a legislative decision "entitled to deference." Id. at 2867-70.

This admittedly broad exemption may nevertheless be deemed "partial" in the sense that Title VII's other anti-discrimination provisions apply to religious employers. See, e.g., Bob Jones Univ. v. United States, 461 U.S. 574 (1983), discussed supra note 109; EEOC v. Mississippi College, 626 F.2d 477 (5th Cir. 1980), cert. denied, 453 U.S. 912 (1981), described supra note 120. Thus, Amos merely allows parochial schools to discriminate against personnel for religious reasons-a privilege this Note supports. $C f$. supra note 145 (Catholic school may fire teacher who flouts Catholic beliefs).

155. Some states have determined that exclusion of church institutions from labor acts is unnecessary. See infra note 156. Presumably, though, legislatures intend that labor boards apply statutory provisions sensitive to the religious concerns of sectarian employers. Whether implicit or explicit, such lawmaking efforts to facilitate free exercise do not violate the establishment clause. See id.

156. For example, Amos involved Congressional efforts to protect free exercise: A court must uphold such a legislative accommodation-even one that exceeds that required by free exercise-unless it violates the establishment clause by aiding or sponsoring religion. $107 \mathrm{~S}$. Ct. at 2867-70. See also Wallace v. Jaffree, 472 U.S. 38, 82-83 (1985) (O'Connor, J., concurring) (courts must "define the proper Establishment Clause limits" on legislative accommodations to prevent government "endorsement" of religion). In contrast, New York's legislature denied a special exemption for religious employers in its labor relations act. See supra notes 150 \& 155 . Thus, the statute cannot raise an establishment clause problem. Instead, the sole judicial inquiry is whether application of the act violates the free exercise rights of a church employer in a particular case. See generally McConnell, supra note 152, at 30-31 (legislative accommodation requires only prima facie free exercise claim, whereas judicial exemptions must be "confined to the most serious burdens"). See also Thomas v. Review Bd., 450 U.S. 707, 722-27 (1981) (Rehnquist, J., dissenting) (because Sherbert v. Verner, 
exercise clause compels this extreme step to remedy a significant infringement of religious rights. ${ }^{187}$ Therefore, the Supreme Court has no authority to invalidate a state labor relations act absent evidence of a specific constitutional violation. ${ }^{158}$

\section{ConClusion}

Labor board regulation of parochial schools poses unique legal problems, yet illustrates the more general struggle to reconcile statutory requirements with the First Amendment. Courts best protect free exercise values by recognizing only documented claims of burdens on religious beliefs and practices and by accommodating religious activity only to the extent necessary to secure constitutional rights. Blind acceptance of all asserted "religious" objections to enforcement of important government policies frustrates rather than serves the objectives of the religion clauses.

374 LI.S. 398 (1963), requires (.ourt to carve statutory exceptions that Lemon v. Kurtzman, 403 U.S. 602 (1971), forbids legislatures to make, expansive interpretation of both clauses should be abandoned to allow legislatures greater flexibility).

157. See supra notes 60-62 and accompanying text (discussing Wisconsin v. Yoder, 406 U.S. 205 (1972)).

158. An unfounded assumption (not shared by the legislature) that free exercise problems might occur is an insufficient basis to strike down a statute. The absence of any facts supporting the clengy's claims of unconstitutional interference was crucial to the decisions in Catholic High School Ass'n v. Culvert, 753 F.2d 1161 (2d Cir, 1985), and Grutka v. Barbour, 549 F.2d 5 (7th Cir.), cert. denied, 431 U.S. 908 (1977). 